\title{
How the Grade of Education Influences Wages in Different Phases of Economic Cycle: Case of the Czech Economy
}

\author{
Petr Doucek $^{1, a}$, Lea Nedomova ${ }^{1, b}$ \\ ${ }^{1}$ University of Economics, Prague, Faculty of Informatics and Statistics, Department of System \\ Analysis, W. Churchill Sq. 4, 13067 Prague 3, Czech Republic. \\ adoucek@vse.cz, bnedomova@vse.cz
}

Keywords: Education level; nominal wage; economic cycle; inflation rate; open economy.

\begin{abstract}
This article analyses the evolution of wages in the Czech Republic by education level. The Czech Republic is an example of a small open economy heavily dependent on the neighbouring countries. The collected data, representing a continual time series from 2000 to 2014, contain annual records of approximately 1,900,000 wages in the Czech Republic structure by different criteria, including education level. For the purposes of the article we chose the following five education levels: Primary, High School, Bachelor, Master, and PhD. The data on average nominal wages converted to the euro are further broken down according to the economic cycle into a period of economic boom in 2000-2008, economic crisis 2008-2011, and a period of economic recovery in 2011-2014. To analyse the data we used tools for analysing time series and approximated the trends with a linear function. Quality of the estimate is measured with the method of least squares. The results show that an education level affects significantly the wage amount. For the period of economic boom we succeeded in identifying the upwards wage trends in all the categories concerned. The growth dynamic was highest in highest education and declined together with declining education level. The crisis period points to contradictory conclusions caused by the fall in the rate of the local currency. In the period of recovery the fall in the local currency rate caused a decrease in the nominal wage in all the categories under review.
\end{abstract}

\section{Introduction}

Over the last fifteen years economies of most European countries have undergone far-reaching changes. The community of the old Member States expanded in two waves in 2004 and 2007, (the last acceding state being Croatia in 2013) with more members whose economies were not so advanced. These countries had to go through a period of transition from centrally controlled economy to market economy. Only after this could they move towards European integration. Some of the Member States use the common currency, the euro, while some have kept their local currency. This is the case of the Czech Republic which acceded to the structures of the European Union in 2004 but kept its local currency, the Czech crown (CZK).

The Czech economy is a small open economy with a long tradition of industrial and agrarian production. At present, the population of the Czech Republic stands at about 10.5 million inhabitants, of whom a total of 7.2 million are employed. Unemployment rate is $6.1 \%$ (as of March 2016). GDP, annual inflation rate is shown in Fig. 1, evolution of yearly changes in the GDP is also shown in Fig. 1. The original foreign trade orientation of the Czech economy towards countries of the former Soviet Union has been replaced with Western orientation towards countries of the European Union, in particular Germany. This one-sided orientation is being extended with cooperation with Far East countries such as China and Korea.

A number of studies and experts analyse the evolution of wages in the world and in the European Union [1, 2, 3]. This article proposes a somewhat different perspective with regard to wages as it analyses wages in the Czech economy by education levels [4, 5, 6]. Thus it offers an answer to the question whether in makes sense to invest in education and whether such an investment pays off in the future.

\subsection{General economic conditions of the Czech Republic}

Every worker who enters an economy moves within an economic system. Regardless of the type of system it can be characterised with these indicators: gross domestic product, inflation rate, and in 
case of an economy with a local currency, the exchange rate of the currency against a world currency or a currency dominant in a given region. The distinctive characteristics of the Czech economy are shown in Fig. 1.

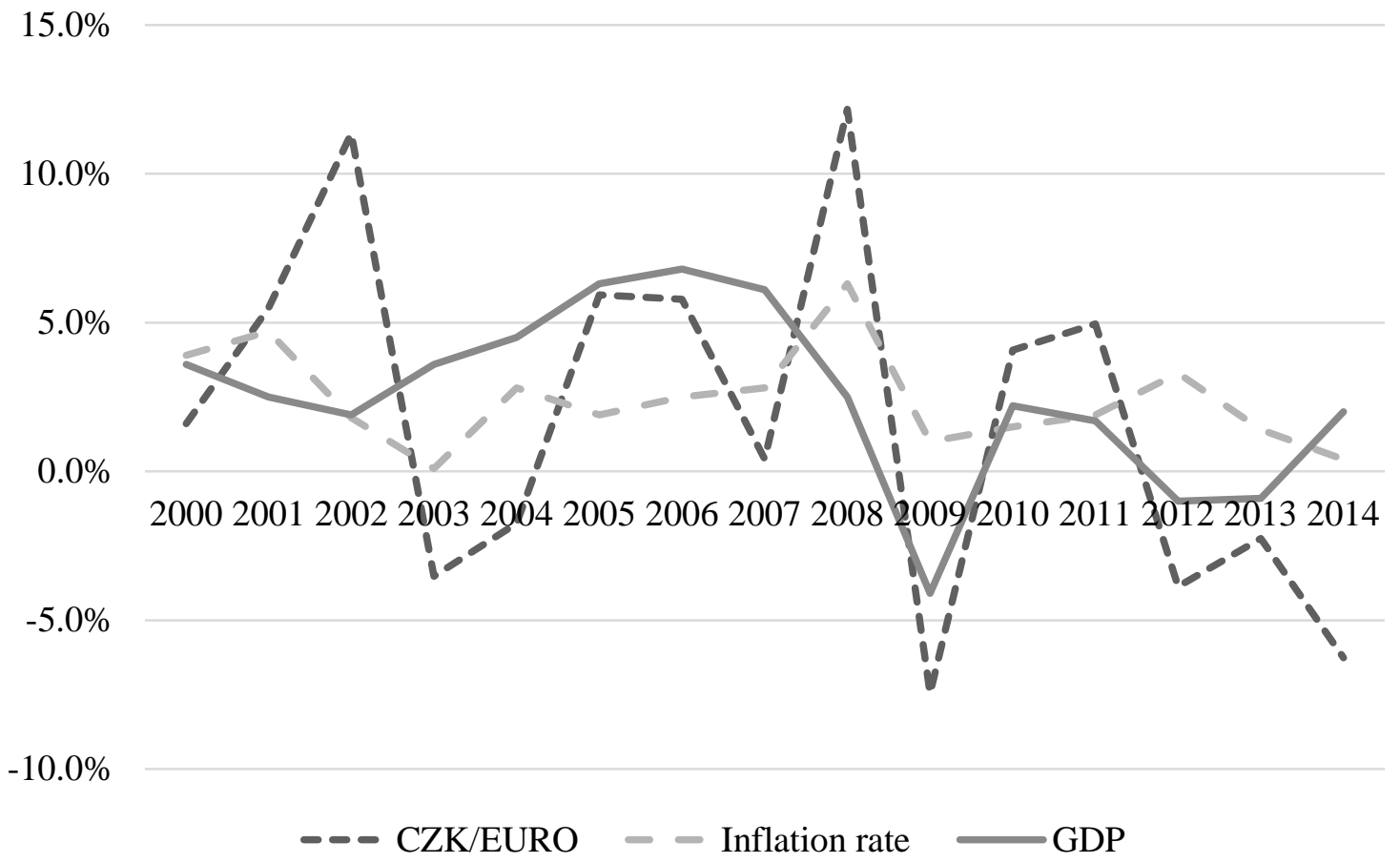

Fig. 1 Evolution of defining macroeconomic characteristics of the Czech Republic in the period under review $[7,8]$

Since 2008 the evolution of GDP of the Czech Republic has matched closely the evolution of the GDP of the European Union. It follows that the Czech economy is its integral part. This integrity need not reflect certain anomalies in the evolution of wages shown in the findings.

\section{Research Questions}

This article analyses the evolution of wages by education level in the Czech Republic $[9,10,11]$. The evolution is analysed according to the economic cycles (economic boom, crisis and recovery [12]). It aims to demonstrate with the example of the small open economy of the Czech Republic with a local currency changes in the trends in the wage evolution caused by the economic cycles economic growth, crisis and subsequent recovery. Another dimension is assessment of the influence of the local currency and some selected macroeconomic factors on the trends [13].

\section{Methodology and Data Collection}

This part of the article contains information about the source of the data and classification of the educational categories as defined in the methodology of the European Union and of the Czech Statistical Office, and description of methods and analytical tools I used to produce the results.

\subsection{Data acquisition and analysis}

The data that were provided by the Czech Statistical Office (CSO) were used to determine the annual inflation and the exchange rate of the Czech crown against the euro. The research and analysis of the gross nominal wages focused on five categories of education level in Czech society [14]. These are Primary - completed primary education with 8 or 9 grades from the age of six, High School - secondary education following primary education and is completed when the student is aged 17-18, Bachelor - first degree of university education usually lasting three years and completed with state bachelors examinations, Master - following bachelor's study, usually lasting two years in economic disciplines, PhD - doctoral study following at highest level previous university studies, usually lasting three or four years. 
The main source of the data for the survey on the evolution of wages was Labour Force Survey conducted every year by the firm Trexima, Ltd. for the Ministry of Labour and Social Affairs of the Czech Republic [15]. The annual data are about approximately 1,900,000 employees of economic operators in the Czech Republic. All responses include information about education level, so that the working sample is identical with the Labour Force Survey sample. Trend analysis was carried out for three periods: period of economic boom in 2000-2008, crisis period in 2008-2011, and finally for the period of expected economic recovery in 2011-2014.

The collected data were analysed using tools and statistical functions of MS Excel for analysis of time series. We employed the linear regression method for ex-post approximation of the wage evolution and the method of least squares to measure the correlation between the estimates and reality. The linear regression method was based on approximation of linear functions using the general formula $y=a x+b$, where constant ' $a$ ' represents the slope of the line of this estimate - the determined evolution trend in the period under review. All regression analysis calculations were performed at $5 \%$ level of significance.

\section{Results and Discussion}

During the period under review the Czech economy transitioned from centrally controlled economy through transition economy to today's relatively developed economy of a European Union Member State [11]. Evolution of wages according to education level is the subject of the following analyses. The wage evolution presented below uses the currency unit, the euro. This fact leaves its trace on the presented results because the exchange rate of the Czech crown has not been constant throughout the period under review and as a result, some significant changes in the relation between EUR against CZK are shown in the conclusions. Evolution of the nominal wage in the Czech throughout the period under review (2000-2014) is shown in Fig. 2.

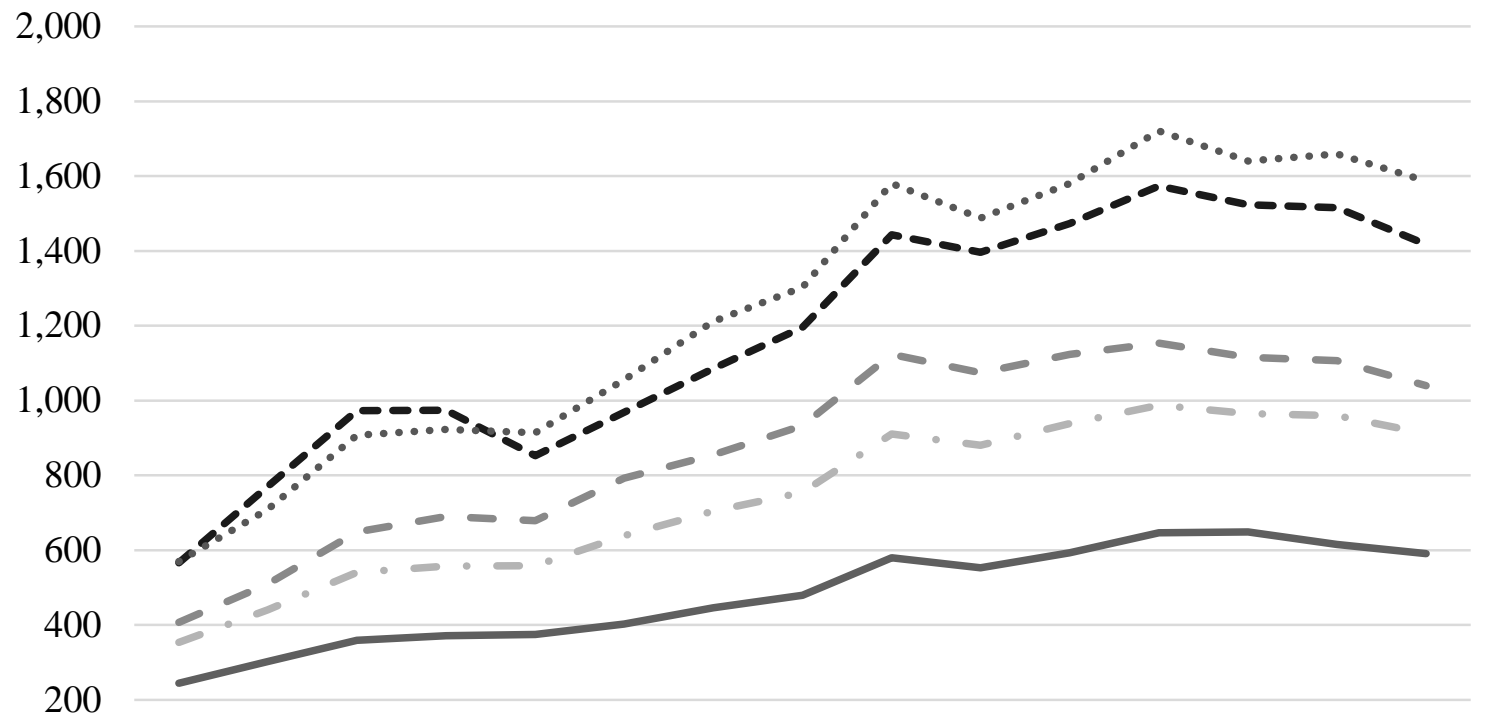

0

200020012002200320042005200620072008200920102011201220132014

— Primary - - High school $\quad$ - Bachelor - - Master ..... Phd

Fig. 2 Evolution of nominal wage by education level

Main conclusions drawn from the analysed data are visible in Fig. 2. Overall, the trend is upward in the long term in all the categories under review, and wages have increased since 2000. Two exceptions are the years 2008 and 2011. I deal with this anomaly in another part of the text. Lowest nominal wages are in the category Primary Education. They are much lower than the other categories (Table 1). It is typical of the High School category that wages in it are significantly higher than the Primary category, but are lower than those in the Bachelor category. The difference between the High School and Bachelor category is significantly lower than the difference between 
High School and Primary categories. The highest wage categories are those of university graduates at the level of Master, and then doctoral graduates in the PhD category. The wage amount depends not only on their qualifications but also on their being in managerial positions and their wages are higher for this reason. The situation is odd in the comparison of wages between the Master and $\mathrm{PhD}$ categories in 2000-2003. The wages are surprisingly higher here than in the Master category. This is due to the fact that the PhD category only began to be used in the employment market after 2003. There were two reasons for this. First, most of them were formerly employed at universities and their wages were therefore lower than those in the economic sphere. Another reason was increased influx of foreign capital to the Czech economy (since about 2003, as a result of a decrease of the exchange rate of CZK against EUR), and hence more demand for workers with a $\mathrm{PhD}$ for middle and upper corporate management. Therefore, the local conclusion for the entire period is that wages rise and the education level are of crucial importance for the amount of one's wage.

Table 1 Analysis of differences in nominal wages by education level

\begin{tabular}{ccccc}
\hline & Primary - High School & High School - Bachelor & Bachelor - Master & Master - PhD \\
\hline 2000 & $45.2 \%$ & $15.1 \%$ & $38.9 \%$ & $0.7 \%$ \\
2001 & $45.3 \%$ & $15.7 \%$ & $51.3 \%$ & $-7.9 \%$ \\
2002 & $50.5 \%$ & $20.0 \%$ & $49.9 \%$ & $-6.8 \%$ \\
2003 & $50.1 \%$ & $23.7 \%$ & $41.1 \%$ & $-5.3 \%$ \\
2004 & $48.8 \%$ & $21.6 \%$ & $25.7 \%$ & $7.2 \%$ \\
2005 & $58.4 \%$ & $24.1 \%$ & $22.3 \%$ & $9.0 \%$ \\
2006 & $58.0 \%$ & $21.3 \%$ & $27.0 \%$ & $11.6 \%$ \\
2007 & $57.2 \%$ & $23.6 \%$ & $28.2 \%$ & $9.0 \%$ \\
2008 & $57.1 \%$ & $23.4 \%$ & $28.5 \%$ & $9.5 \%$ \\
2009 & $59.1 \%$ & $22.0 \%$ & $29.9 \%$ & $6.5 \%$ \\
2010 & $58.1 \%$ & $19.7 \%$ & $31.1 \%$ & $7.3 \%$ \\
2011 & $52.8 \%$ & $16.8 \%$ & $36.5 \%$ & $9.3 \%$ \\
2012 & $48.8 \%$ & $15.5 \%$ & $36.5 \%$ & $7.7 \%$ \\
2013 & $55.8 \%$ & $15.4 \%$ & $37.0 \%$ & $9.5 \%$ \\
2014 & $54 \%$ & $14.1 \%$ & $36.2 \%$ & $12.0 \%$ \\
Average & $53.3 \%$ & $19.5 \%$ & $34.7 \%$ & $5.3 \%$ \\
Difference & & & & \\
\hline
\end{tabular}

Note on Table 1: One hundred percent is the nominal wage in the lower education category in a given year. The value in the table indicates how many percent a worker in the higher education received more than a worker in the lower category.

Following Table 2 shows the results of regression analysis which I applied to three parts of the economic cycle as they appeared in the Czech economy.

Table 2 Analysis of evolution of nominal wages by economic cycle periods and by education level

$\begin{array}{llll}\text { Degree of Boom } & \text { Crisis } & \text { Recovery Phole Period }\end{array}$

Education/Phase of

Economic Cycle

\begin{tabular}{ccccc}
\hline Primary & $\mathrm{y}=34.626 \mathrm{x}+222.62$ & $\mathrm{y}=23.976 \mathrm{x}+533.25$ & $\mathrm{y}=-19.801 \mathrm{x}+675$ & $\mathrm{y}=28.364 \mathrm{x}+253.8$ \\
& $\mathrm{R}^{2}=0.9292$ & $\mathrm{R}^{2}=0.6288$ & $\mathrm{R}^{2}=0.8719$ & $\mathrm{R}^{2}=0.9138$ \\
High School & $\mathrm{y}=59.575 \mathrm{x}+308.73$ & $\mathrm{y}=8.958 \mathrm{x}+856.84$ & $\mathrm{y}=-23.507 \mathrm{x}+1014.7$ & $\mathrm{y}=45.31 \mathrm{x}+377.68$ \\
& $\mathrm{R}^{2}=0.946$ & $\mathrm{R}^{2}=0.6749$ & $\mathrm{R}^{2}=0.8917$ & $\mathrm{R}^{2}=0.9065$ \\
Bachelor & $\mathrm{y}=77.406 \mathrm{x}+350.5$ & $\mathrm{y}=13.882 \mathrm{x}+1083.8$ & $\mathrm{y}=-34.842 \mathrm{x}+1191.1$ & $\mathrm{y}=51.298 \mathrm{x}+473.04$ \\
& $\mathrm{R}^{2}=0.9514$ & $\mathrm{R}^{2}=0.3033$ & $\mathrm{R}^{2}=0.9126$ & $\mathrm{R}^{2}=0.8521$ \\
Master & $\mathrm{y}=83.37 \mathrm{x}+564.25$ & $\mathrm{y}=46.863 \mathrm{x}+1354.4$ & $\mathrm{y}=-47.857 \mathrm{x}+1627.2$ & $\mathrm{y}=66.608 \mathrm{x}+649.07$ \\
& $\mathrm{R}^{2}=0.8279$ & $\mathrm{R}^{2}=0.6471$ & $\mathrm{R}^{2}=0.8849$ & $\mathrm{R}^{2}=0.8661$ \\
PhD & $\mathrm{y}=109.35 \mathrm{x}+472.42$ & $\mathrm{y}=51.464 \mathrm{x}+1463.6$ & $\mathrm{y}=-38.402 \mathrm{x}+1747.7$ & $\mathrm{y}=81.806 \mathrm{x}+602.06$ \\
& $\mathrm{R}^{2}=0.9393$ & $\mathrm{R}^{2}=0.4769$ & $\mathrm{R}^{2}=0.8012$ & $\mathrm{R}^{2}=0.9083$ \\
\hline
\end{tabular}

Wages were rising throughout the period under review and the highest dynamic is in the $\mathrm{PhD}$ category - approximation line slope is 81.8 (with estimate reliability of 0.908 ). With lower education the dynamic of evolution of the average wage decreases in the period under review. 
Lowest estimate reliability throughout the period under review is in the Master category, but this value is not significant from the perspective of following the trend because in comparison with the other categories it is lower by approximately 5 percentage points.

The period of economic boom (2000-2008) is characterised by practically continual wage rises in all the categories. An exception is a wage decrease in the Master category between 2003 and 2004, when in managerial positions of supranational and international enterprises they were replaced by university graduates in the $\mathrm{PhD}$ category with even higher education. This is why the estimate reliability in the Master is lowest of all the categories, being only 0.828. Growth dynamic is again highest in the PhD category and lowest in the Primary category.

A remarkable anomaly is the year 2008 - on the border between boom and crisis. Nominal wages increased sharply in line with an increase in inflation. As a result, annual increase in real wages was only $2.0 \%$. The causes of the increase in nominal wages and subsequent inflation include:

- a significant fall in unemployment in the Czech economy when short-term inflation was practically zero,

- an increase in the number of vacancies, in particular in the High School and Bachelor categories,

- introduction of new environmental taxes initiated by the European Union.

The subsequent decrease in nominal wages in 2009 resulted from a steep fall in the exchange rate CZK against EUR (Fig. 1).

The period of crisis (2008-2011) is marked by completely different trends in all the education categories under review. This was caused by the relatively short period for the analysis of the ascertained values and the fact that the whole economy was not hit by the crisis at the same time and the crisis erupted at different times for different sectors. Characteristic of the whole period is a decline in the growth dynamic with the greatest decline in the Bachelor category. Also, the degree of estimate reliability for the behaviour of the approximation line significantly decreased. The reason for this is the short period when the drop in the exchange rate in 2009 was followed by its increase in 2010 and growth stagnation in 2011. Here the wage analysis is significantly affected by the local currency rate against the euro.

The period of recovery (2011-2014) is characterised by a fall in nominal wages in all the categories. This fall was not caused so much by the real fall in the wages (if we analyse the local currency we will see in this period by very modest growth) and it is caused by the fall in the local currency exchange rate (Fig. 1). This measure was taken and is taken by the central bank (interventions in the FX market). Therefore, the economic recovery is paid for by a decrease in the local currency exchange rate and the decrease in the nominal wages caused by this. It is interesting that the sharpest fall in in the Master category - approximation line slope is -47.86 with estimate reliability 0.885. Another declining category is $\mathrm{PhD}$ (slope -38.4, estimate reliability 0.812), followed immediately by the category Master (slope -34.84 , estimate reliability). Lowest dynamic is in the Primary category.

\section{Conclusions}

The conclusions can be divided into two groups. The first are generally applicable, in particular:

- Throughout the period under review wages rose in all the education categories.

- Investment in education pays off because the differences between the categories are substantial. They are greatest in the Primary and High School categories, where the average difference in the period under review is $53.3 \%$ of the average monthly wage than the Primary category. The difference is not so marked in the High School and Bachelor categories that are between secondary education and the lowest degree of university education (averaging in the period under review 19.5\%). A relatively higher difference is visible (Table 2) in the Bachelor and Master categories. Here the difference is on average 
$34.7 \%$ of the wage in the Bachelor category. I observed a very small difference in the wages in the Master and PhD categories, only 5.3\%.

- The trends influenced by the economic cycle are evident in Fig. 1. The growth period also represents a rise in wages, and the period of crisis is characterised by the decrease in the wages, and the period of recovery leads to a decrease in the nominal wage.

- Faster wage growth dynamic as well as wage decreases is observed in the higher education category.

- Start of economic growth after the crisis in a small country with an open economy is paid by a decrease in the rate of its local currency and thereby, increased competitiveness of its production in the international market. On the other hand, this has negative consequences for the amount of the wages received by its workers in comparison with economies of other countries.

The other groups of conclusions are those I drew for the individual economic cycle periods, in particular:

- The period of boom is characterised by wage increases in all the categories under review. Growth tempo is higher in the higher education categories. Between 2000-2004 the wages in the Master category were higher than those in the $\mathrm{PhD}$ category because an increase in the number of workers with a $\mathrm{PhD}$ in the general economic practice only occurred in the Czech economy outside the universities after 2003 as a result of the influx of foreign capital and increased market share of international and supranational enterprises in the Czech Republic. Linear approximation of the evolution using the regression function with a $5 \%$ degree of significance demonstrates relatively good reliability from 0.946 in the High School category to 0.838 in the Master category. Further macroeconomic influences were not much manifested (including fluctuation of the local currency exchange rate against the euro).

- The period of crisis - here the analysed trends in the behaviour of the average nominal wages changed from the preceding period. Wage growth dynamic declined (Fig. 2, Table 2.), although wages still rose despite a decrease in the GDP (Fig. 1). Estimate reliability decreased markedly using the regression function where the highest values were identified in the Master category - 0.647, and by contrast, the lowest value was in the Bachelor category -0.303 . In this period the highest dynamic was in the $\mathrm{PhD}$ category. The decrease in the CZK exchange rate against the euro in 2009 affected significantly the conclusions of the analysis because it represented $7.5 \%$ compared with the previous period. The wages thus decreased for one year and this made the whole approximation fluctuate and the estimate reliability was reduced.

- The period of recovery is congruent with respect to the evolution trend of the average nominal wage and its quantification in euros. A decrease according to education is visible in all the categories under review. This situation is not however caused by the wage evolution but by a relatively marked reduction in the local currency exchange rate. In the period of recovery the greatest wage reduction dynamic is in the Master category with -47.86 . Another declining category is the $\mathrm{PhD}$ with -38.4 , followed immediately by the Master category with -34.84. Estimate reliability value ranges from $0.801(\mathrm{PhD}$ category) to 0.913 in the Bachelor category.

\section{Acknowledgment}

Paper was processed with contribution of long term institutional support of research activities by Faculty of Informatics and Statistics, University of Economics, Prague. IP 400040. 


\section{References}

[1]. I. Malá, "Vícerozměrný pravděpodobnostní model rozdělení prř́jmů českých domácností," in Politická ekonomie, vol. 63, no. 7, Oeconomica: Prague, 2015, pp. 895-908.

[2]. L. Marek, “Analýza vývoje mezd v ČR v letech 1995-2008,” in Politická ekonomie, vol 58, no. 2, Oeconomica: Prague, 2010, pp. 186-206.

[3]. L. Marek, "Some Aspects of Average Wage Evolution in the Czech Republic," International Days of Statistics and Economics, Prague, Slaný: Melandrium, 2013, pp. 947-958.

[4]. D. Bílková, "Financial Position of Czech Employees at the Beginning of the 3rd Millennium According to Educational Attainment," in Prague Economic Papers, vol. 24, no. 3, Oeconomica: Prague, 2015, pp. 307 - 331.

[5]. L. Marek and M. Vrabec, "Model wage distribution - mixture density functions," in International Journal of Economics and Statistics, vol. 1, no. 3, North Atlantic University Union, 2013, pp. 113-121.

[6]. M. Maryska, P. Doucek, and L. Nedomova, “ICT professionals' wages development,” Liberec Economic Forum. Liberec: Technical University of Liberec, 2015, pp. 101-111.

[7]. HDP - vývoj hdp v ČR http://www.kurzy.cz/makroekonomika/hdp/?G=3\&A=2\&page=1

[8]. Mzdy - vývoj mezd, http://www.kurzy.cz/makroekonomika/mzdy/?G=1\&A=1\&page=2

[9]. L. Nedomová and P. Doucek, "Gender Aspects in ICT," International conference of management and industrial engineering," Bukurešt': NICULESCU, 2015, pp. 508-516.

[10]. P. Doucek, L. Nedomova, and M. Maryska, "Is It Attractive To Be the ICT Professional in the Czech Economy?” IDIMT-2015 Information Technology and Society Interaction and Interdependence. Linz: Trauner Verlag Universität, 2015, pp. 73-88.

[11]. F. Webster, "What Is Information Society?” in The Information Society, vol. 10, no. 1, Taylor \& Francis, 1994, pp. 1-23.

[12]. L. Nedomova, P. Doucek, and M. Maryska, "ICT Professionals in the Czech Economy, Structural Changes in Human Resources,” Proceedings of the 11th international conference on Strategic Management and its Support by Information Systems 2015 (SMSIS), Ostrava: VŠB TU FE, 2015, pp. 419-430.

[13]. P. Drucker, “The Age of Discontinuity,” Heinemann, 1969.

[14]. J. Hanclova, "Minimum Wage Impact on Wage and Unemployment Distribution in the Czech Republic," Proceedings of the 24th International Conference Mathematical Methods in Economics 2006. Pilsen: University of West Bohemia, 2006, pp. 213 - 220.

[15]. Ministry of Labour and Social Affairs of the Czech Republic, unpublished. 